\title{
Website Quality and the Role of Travel Perceived Risk in Influencing Purchase Intention: A Study on Bali Tourism Board's Official Website
}

\author{
Christian Alianto ${ }^{1,}$ Hatane Semuel ${ }^{1,}$ Serli Wijaya ${ }^{1 *}$ \\ ${ }^{1}$ Faculty of Business and Economics, Petra Christian University, Surabaya, Indonesia \\ *Corresponding author.e-mail: serliw@petra.ac.id
}

\begin{abstract}
There has been an increased intensity in the use of the website as a strategic means for marketing a destination. Out of all local tourism government's official websites, The Bali Bible (www.thebalibible.com), managed by Bali Tourism Board (BTB), is observed to be the most comprehensive tourism website which allows tourists to explore Bali before the visit. The website facilitates tourists to purchase the tourism-related products and services offered such as accommodation, local transportation rent, and tickets of tourist attractions in Bali. This study aimed to examine the effect of website quality of the Bali Tourism Board on purchase intention with travel perceived risk as a moderating variable. The survey was completed to 239 respondents who had ever surfed on the Bali Tourism Board website. The result of the study revealed that website quality could significantly enhance the intention to purchase directly on the website. While travel perceived risk had a direct influence on purchase intention, it appeared not to be a significant moderating variable that contributes to the effect of website quality on the intention to purchase on the website. Through these results, recommendations are offered to relevant destination stakeholders to improve the website management.
\end{abstract}

Keywords: Website quality; bali tourism board; perceived travel risk; purchase intention.

\section{INTRODUCTION}

The internet users in Indonesia increases sharply from 0.5 million users in 1998 to 171,17 million users in 2018, and it is predicted to keep increasing significantly forward [1]. The increase triggers government to take advantage of internet technology to enhance the performance in any sectors including tourism sector [2]. The presidential instruction No. 3/2003 on national policy and strategy to develop e-Government is one of government serious manifestations concerning the utilisation of information and communication technology. The use of e-Government is seen in any public services including the official website of local tourism government board as communication media for regional tourism marketing [2]. Tourism website as the first gate for tourists becomes essential to facilitate tourists who plan either domestic travel or international one [3]. The utilisation of digital platform for regional tourism promotion is obviously relevant to government target to attract more than 20 million international tourists and 275 million domestic tourists to visit any tourist destinations in Indonesia (Statistics Indonesia, 2018) without specifically relating it to website quality [5-8],

Website quality turns out to be very crucial to measure the effectiveness of marketing communication and online selling [4]. A number of prior studies have been conducted mainly focusing on selling promotion of online shopping whereas empirical studies measuring website quality of Indonesia official tourism haven't been done much 
[9]. Also, studies which particularly examine the influence of website performance as marketplace over tourists' intention to purchase trip package online are rarely done. One of consumer's main concerns when surfing website which functions as marketplace is security risk when making use of both facility and service of website. Website with fine standard quality becomes an important factor which affects the consumers' intention to decide either to purchase or to leave the product and service offered by the website [10]. A fine standard website quality is able to lessen the perceived risk by customers [11]. In the tourism context, travel risks generally are health risk, safety risk, accident risk, and else [12]. Perceived travel risk owned by tourists can be lessened by seeking information through the internet related to the intended visit [13].

Of the previous studies, there are inconsistent results concerning the website influence over purchase intention. Some studies confirm that website quality has a significantly positive effect on tourists' purchase intention [9], [14], [15]. Conversely, others reveal an insignificant effect [16]. In addition, some other studies even find a negative effect towards purchase intention [10]. Meanwhile, studies on perceived travel risk as a moderating variable between website quality and purchase intention relatively have not been done so far. Previous studies show that perceived travel risk has positive effect on purchase interest [17], yet, sometimes it also negatively affects purchase intention [18], [19].

Upon the discrepancies discussed above, this study aims to investigate the influence of website quality over tourists' perceived travel risk and purchase intention of tourism- related product and service on website. Following secondary data observation of ten local government websites in Indonesia, the researchers decide to select the official website of Bali Tourism Board (BTB) which its URL address is www.thebalibible.com as the research object considering the fact that government website of Bali Province, Bali Tourism Board, is assessed to be the most attractive and comprehensive in terms of its management. To be more specific, this study is conducted to uncover the anwers of three purposes:

(1) Analysing the influence of BTB website quality over purchase intention on BTB website.

(2) Analysing the influence of perceived travel risk over tourists' purchase intention on BTB website

(3) Analysing the influence of BTB website quality over purchase intention on BTB website with perceived risk travel as a moderating variable.

\subsection{Related Work}

\subsubsection{Website Quality}

Website quality (webqual) is website suitability for shareholders [20]. Webqual has been developed from its first version, webqual 1.0 to webqual 4.0 [2]. Webqual
4.0 is different from its prior version that it stresses more on customers' perception than on website designers [2]. Webqual is also used in other sectors, such as government, private business, and even smartphone applications [22- 26]. Webqual comprises three dimensions, which are usage, information quality, and interaction quality, all of which consist of 23 indicators [26]. Usage describes website quality on appearance/interface, ease of use, and navigation to customers; Information quality covers content quality and information suitability for customers' needs such as accuracy, format and relevance; While interaction quality is more of transaction, information security and communication to website [26].

\subsubsection{Perceived Travel Risk}

Perceived travel risk is defined as fear and discretion of tourists over negative experience which is likely to take place due to anxiety of either health or danger [28-29]. Perceived travel risk is similarly defined as uncertainty over desired/expected result [29] for instance physical risk, financial risk, performance risk, social-psychological risk, and time risk [30]. Referring to aforementioned risks [30], physical risk can be in forms of terrorism and disease in intended destination such as virus whereas financial risk is about the extra expense outside the travel package. While performance risk is either about less destination/new attraction, boredom, or destination's cleanliness, time risk is about the trip which may waste customers' time. [31] leads to explain another risk that is inconvenient trip in the destination, for example traffic, safety food and else.

\subsubsection{Purchase Intention}

Intention is how desirable someone to do something and to predict action or behaviour [32]. Intention is closely associated to purchase intention which is to buy either product or service and this is affected by a number of variables such as appearance/interface [34-36]. It is to explain that purchase intention is affected by several variables including product attributes: product information, quality and price. Information quality of a particular website matters that it facilitates purchase intention [36]. According to [37], purchase intention is measured by transactional interest, referential interest, preferential interest and exploration interest. Transactional interest is tendency to purchase product/service, whereas referential interest is how customers refer the product/service to others. While preferential interest is described as tendency to select the product over other products, exploration interest is when customers look into some information of product/service [37]. 


\subsubsection{The Relationships among Webqual, Perceived Travel Risk, and Purchase Intention - Hypotheses Development}

Fine website quality (webqual) is likely to influence not only purchase intention but also revisit website [38]. [15] and [39] prove that webqual holds significant influence over purchase intention. A study on online shopping at Kunming confirms that ease of use has significant both direct and indirect effect towards purchase intention [40]. The influence of information quality and purchase intention results in various effects; Of the online shopping at Kunming, information quality does not significantly affect the purchase intention [40] whereas of the flight ticket service in Mongolia, it has significantly positive effect [10]. Additionally, Interaction quality holds significant influence towards purchase intention on the study of online shopping at Kunming [40]. Risks such as physical risk, performance risk, social appreciation risk, time and psychology risk, financial and personal satisfaction risk, have significantly negative influence over travel intention [19]. [19] states that the government needs to take some steps to lessen the risks and enhance travel intention by campaigning under the theme that destination is safe from risks. According to [28], perceived travel risk is also depended on the condition of destination, for example protests, riots, bombing in Thailand caused fear for the tourists. Therefore, the only risk which has a significant effect is political risk. Another thing is when the number of tourists visiting China decreased, [42] tested perceived cognitive and affective risks and discovered that it is only perceived affective risk that has significantly negative effect since the risk is in form of feeling. Based on this discussion, the first and second hypotheses are formulated as follows:

$\mathrm{H}_{1}$ : Webqual influences/affects purchase intention

$\mathrm{H}_{2}$ : Perceived travel risk influences/affects purchase intention

However, webqual and purchase intention can also be moderated by perceived travel risk. Regardless of being less frequently conducted, this hypothesis is supported by [41] which states that terrorism, culture barrier, and dogma risk can play as moderators. Referring to this discussion, the third hypothesis is formulated below: $\mathrm{H}_{3}$ : Perceived travel risk moderates the relation between webqual and purchase intention

\subsection{Our Contribution}

This study aims to examine the influence of perceived travel risk as a moderating variable between website quality and purchase intention. Correspondingly, the influence of Webqual and perceived travel risk are tested independently over purchase intention. The consistency of previous similar studies will be confirmed by this study. Additionally, it will contribute to provide suggestion for the relevant tourism destination stakeholders.

\subsection{Paper Structure}

The rest of this study comprises as follows: First, website quality, perceived travel risk, purchase intention, and the relationships among the concepts and research hypotheses are presented. Second, research method administered in this research is described. Thirdly, findings of the research are discussed. Lastly, conclusion, recommendation, and direction for future research are offered.

\section{METHODS}

This research uses primary data gathered from a survey with a questionnaire as the tool and administered with quantitative approach which employs data, information and model for empirical analysis [43]. The population is the internet users residing in Indonesia and have used online travel agent services like Traveloka, Agoda, Airbnb, Pegipegi, tiket.com, Airy, Trivago, and others. The technical sampling is purposive sampling based on criteria as follows: 1) have used the travel trade service for the past two years; 2) be minimum of 17 years old; and 3) have browsed BTB website. For those who haven't ever visited BTB website, they were directed to browse it first. The sample gathering employs design experiment method which collects and analyses data based on the information of variations from both under control and not undercontrol [44]. This method, employed due to Covid-19 pandemic which requires social distancing, is divided into three roups; They are public society, Petra Christian University students of Tourism Management and Hospitality Management programs as they have more exposure and intensively interact with tourism and hospitality industries. Having benefited from video conference facility of Google Meet, researchers explained the research purposes and directed the respondents at protocol and technique of filling in the questionnaire. The total samples in filling in the questionnaire are 239 respondents.

The questionnaire consists of three parts: 1) screening questions (3 items); 2) respondents' profile 916 (items); and main questions (25 items). The main questions comprise webqual (15 items) [46], [25], perceived travel

risk (6 items) [31-32, and purchase intention (4 items) [37]. This questionnaire employs Likert scale from 1 (strongly disagree) to 5 (strongly agree). The questionnaire data then are processed with SmartPLS 3.0.

To assess validity and reliability of research 
instruments, pilot study was administered to $30 \quad$ March to April 2020. respondents. The primary data collection was done from

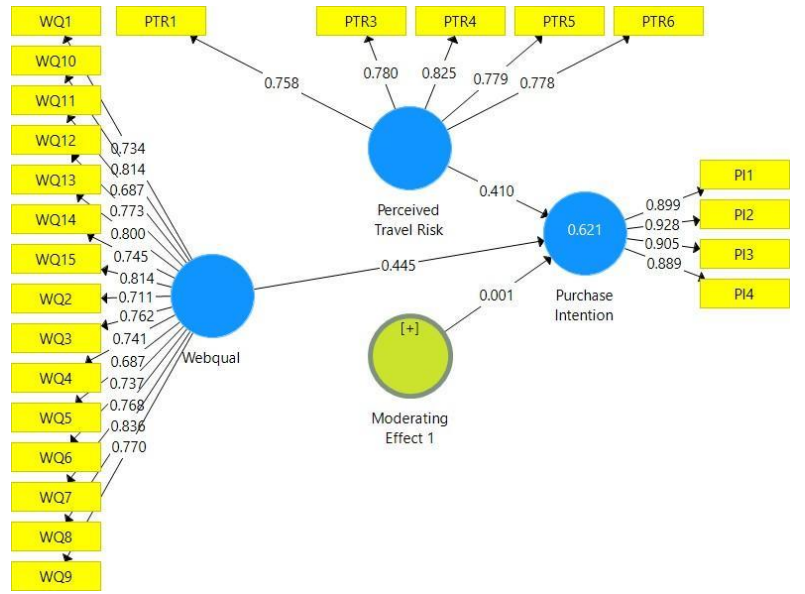

Figure 2. Summary of Tested Model

\section{RESULTS}

The participants of this study are dominated by those within age range of 17-25 years old and university students. Most of the respondents have income or pocket money (for students) between IDR 2-6 million per month, and live with family with four family members. Related to travel behaviour, most of the respondents stated that the last visited destination was in Indonesia, had the trip with family for 3-4 days. Meanwhile, the other respondents who travelled abroad declared that they spent longer around 5-6 days than those of domestic travel. In terms of internet usage, the collected data show that majority of the respondents use the internet for more than 5 hours per day in average for social media. Along with high intensity of browsing the internet, it is not surprising if as much as $93.7 \%$ of respondents reported that they gained tourist destination information through the internet.

In this research, website quality is measured by three dimensions, namely usability, information quality, and interaction quality.

The result of descriptive statistic shows that of those three dimensions, website quality and usability dimension are perceived well by the respondents whereas the performance of interaction quality is perceived less well. Majority of the respondents agree that BTB website has an attracting interface. On the contrary, the indicators which refer to $\mathrm{BTB}$ website reputation are perceived low since not all the respondents are in agreement that BTB has a trusted reputation.

Related to respondents' perceived travel risk, it reveals that some tourists perceive Bali still unsafe from terrorism risk. Even so, most of the respondents have one voice of the time spent in Bali not wasted. Also, those respondents agree on the fact that while they are browsing the BTB website, they not only find complete information about BTB but also able to purchase tourism product.

The PLS Algorithm analysis on table 1 shows that all actions/treatments have gone through some conditions like outer and inner model. This research successfully passes the outer model test which consists of convergent validity, Average Variance Extracted (AVE), discriminant validity, and Cronbach's alpha and composite reliability whereas the inner model comprises determining coefficient $\left(\mathrm{R}^{2}\right)$, cross-validated redundancy or Stone-Geisser $\left(\mathrm{Q}^{2}\right)$, hypothesis test.

Table 1 displays the hypothesis test in which value of original sample $(\mathrm{O})$ is path coefficient value and $t$ statistics represents whether the hypothesis is accepted or rejected. The influence of webqual towards purchase intention has original sample as much 0.445 which means it has a positive relation. T statistics of webqualPI is 5.243; It means that $\mathrm{H}_{1}$ is accepted and therefore webqual holds a significant effect over P1. The significantly positive effect indicates that the better the quality of BTB website, the higher the purchase intention is. Furthermore, webqual variable is also reflected by WQ3 (outer loading 0.762), WQ8 (outer loading 0.836), and WQ15 (outer loading 0.814).

Next, WQ3 indicator measures the BTB website quality in terms of providing product/service knowledge, while WQ8 indicator is related to BTB website ability to give relevant information needed by tourists. The last is WQ15 indicator which represents the fact whether the offered product in the picture is exactly equal to what it is promised. Above all, the outstanding webqual variable is WQ8 which is general information and can be in forms of assessment from restoran, hotel and else, offered facilities, address, phone number and others. 
Following the effect of perceived travel risk over purchase intention, original sample 0.410 means a positive relation. This relation can bear a positive effect because the used PTR sentences are positive (feeling safe from risks). This relation denotes that the higher the assumption of safe from risks, the higher the purchase intention of the respondents is. T statistics of PTR-PI is 5.897 and it means that $\mathrm{H}_{2}$ is accepted; Consequently, the perceived travel risk holds significant effect towards purchase intention.

The moderating effect relation with independent variable which is webqual on dependent variable is purchase intention (P1) with moderating variable of perceived travel risk (PTR); It has original sample (O) 0.001 . This value indicates that PTR moderates webqual relation to purchase intention positively. Yet, $t$ statistics value does not support the statement of 0.040 which is less than 1.96 and that means $\mathrm{H}_{3}$ is rejected. Therefore, this research model does not experience moderating or known as predictor moderation variable, and it leads to the conclusion that webqual and PTR play an independent role in affecting PI. The higher the website quality is the stronger the purchase intention without being moderated by perceived travel risk.

Table 1. Hypothesis test results

\begin{tabular}{|c|c|c|c|c|}
\hline \multirow[t]{2}{*}{ Hypothesis } & Effect (direct & t Original & \multirow{2}{*}{$\begin{array}{c}\mathrm{t} \\
\text { Statistics }\end{array}$} & \multirow{2}{*}{$\begin{array}{l}\text { Accepted } \\
\text { /Rejected }\end{array}$} \\
\hline & and indirect) & Sample & & \\
\hline & \multirow{2}{*}{\multicolumn{2}{|c|}{$\underline{(\mathrm{O})}$}} & & \\
\hline H1 & & & 5.243 & Accepted \\
\hline $\mathrm{H} 2$ & $\mathrm{PTR} \rightarrow \mathrm{PI}$ & 0.410 & 5.897 & Accepted \\
\hline H3 & Moderating & 0.001 & 0.040 & Rejected \\
\hline
\end{tabular}

Effect $\rightarrow$ PI

\section{DISCUSSION}

\subsection{Summary of Findings}

Webqual holds significant influence over purchase intention $\left(\mathrm{H}_{1}\right)$, which means that the more respondents assess BTB website quality fine, the more purchase intention will be and likewise. The example of this statement is the more BTB website provides relevant information, the more respondents will recommend and choose BTB website to purchase tourism-related product. This hypothesis is supported by [15] that states website service quality in online shopping industry has significantly positive influence towards purchase intention. Another researcher who confirms this result is [9] who declares that information quality is the most agreed part of respondents and can enhance purchase intention. The discrepancy between [9] research and this research is the most agreed of purchase intention variable which is information quality while in this research is usability.

Next, perceived travel risk has a significant influence towards purchase intention $\left(\mathrm{H}_{2}\right)$; It suggests that the more respondents think Bali is safe from risks, the more they intent to buy at BTB website. The statement means the perceived assumption of being safe from risks is bigger (seeing risks lower), therefore respondents want to transact. This hypothesis is supported by [19] on behaviour and intention to travel to Italia where there are three main risks, namely physical, performance, social appreciation; time and psychology; and financial and personal satisfaction, that hold significantly negative effect over travel intention. Due to this situation, government organisation cooperated with tourism agencies to do campaign to lessen the perceived risks. [19] used negative sentence such as " I am not sure Italia fulfills the expectation", and it is different from the sentence in this research "Service in Bali will be like what it's expected". Another supporting research is [18] which was conducted in China and revealed that perceived risk has a significantly negative effect towards travel intention Perceived travel risk does not moderate the relation between webqual and purchase intention $\left(\mathrm{H}_{3}\right)$. That means the influence of website quality towards purchase at BTB is not affected by any probable risks in Bali. The example of this statement is when respondents perceive information provided by BTB website relevant, and they more willingly choose and recommend $\mathrm{BTB}$ website to order tourism-related product disregarding any risks in Bali. This hypothesis is not consistent with [46] which states attitudes towards risks moderate the quality of service, credibility, and image values perceived by medical tourism research in Taiwan where higher perceived value is likely to enhance purchase intention.

\subsection{Managerial Implications}

Managers of tourism website especially BTB need to focus on the quality of both information and interaction since the respondents' answers which less agree on both qualities describe webqual. In addition, 
managers have to offer more online sales promotion programs as Indonesian people mostly are not informed about the website.

Tourism service providers could provide unique and new information to website managers which is targeted specifically at millennial generation so that they are willing to purchase through the BTB website. Moreover, the providers can guarantee that the information given is accurate and reliable to enhance visitors' trust. The information has been seen from the customers about the website itself and Bali which is free of risks.

For the third party, payment parties need to standardise payment methods since different product or service requires different payment. Due to the fact that currently available payment is only credit card, it is essential for the third party to add more payment methods for example transfer or e-commerce.

\subsection{Limitations and Direction for Future Research}

Further research is suggested to add more variables such as customer value which probably will enhance the value of $\mathrm{R}^{2}$ dan $\mathrm{Q}^{2}$. Travel motivation could be added as moderating variable with an assumption that how good the website quality will not increase purchase intention without travel motivation. Besides, respondent selection needs to be more varied to bear richer analysis.

\section{CONCLUSION}

The research aims to investigate the influence of webqual, travel motivation, perceived travel risk, and purchase intention. This research confirms that the hypotheses can be opposite due to different context. If the website quality is fine, more customers will purchase. Perceived travel risk also plays an important role as most customers usually take into consideration the condition of the destination before going travelling. This research suggests a number of recommedations for BTB managerial website, tourist service providers, and the third party, payment method providers. First, the manager needs to promote BTB website more and creates some packages based on this result. Secondly, the tourist service providers are suggested to add more contents to attract customers to transact on website. Thirdly, the third party (payment party) has to standardise all payment methods on BTB website concerning the current situation. Last, adding some variables are likely to promote better result to predict dependent variables. The result may be varied depending on the examined destination and respondents' background.

\section{REFERENCES}

[1] APJII. (2017). Penetrasi \& Profil Perilaku
Pengguna Internet Indonesia. Indonesia: Polling Indonesia.

[2] Permadi, G., et al. (2015). Pengukuran mutu website dinas pariwisata Pacitan menggunakan metode webqual. Jurnal Informa Politeknik Indonusa Surakarta, 1, 11-17.

[3] Feng, R., et al. (2003). East versus west: A comparison of online destination marketing in China and the USA. Journal of Vacation Marketing, 10(1), 43-56.

[4] Zhang, X. \& Prybutok, V. R. (2005). A consumer perspective of e-service quality. IEEE Transactions on Engineering Management, 52(4), 461-477.

[5] Almendros, E. C. \& Gracia, S. D. B. (2016). Online airline ticket purchasing: Influence of online sales promotion type and Internet experience. Journal of Air Transport Management, 53, 23-34.

[6] Chatterjee, P. \& McGinnis, J. (2010). Customized online promotions: Moderating effect of promotion type on deal value, perceived fairness, and purchase intent. The Journal of Applied Business Research, 26(4), 13-20.

[7] Devlin, J., et al. (2007). A study of time limited price promotions. Journal of Product \& Brand Management, 16(4), 280-285.

[8] Manzur, E., et al. (2013). Store price promotion strategies: An empirical study from Chile. Academia Revista Latinoamericana de Administración, 26(3), 356-372.

[8] Shi, Y. (2006). The accessibility of Queensland visitor information centres' websites. Tourism Management, 27(5), 829841.

[9] Jauhari, M. T., et al. (2019). The impact of website quality on consumer satisfaction and purchase intention (study case of e-commerce Lazada Indonesia in Malang city). Jurnal Administrasi Bisnis (JAB), 67(1), 54-61.

[10] Batbayar, M., et al. (2018). Influences of website quality on online purchase intention of air ticketing service: In case of Mongolia. Invention Journal of Research Technology in Engineering \& Management (IJRTEM), 2(6), 13-18.

[11] Goswami, S. (2013). Measuring customer satisfaction on webqual dimension for online banking: An empirical study. Paradigm, 17(12), 25-36.Osland, G. E., et al. (2017). Perceptions of personal risk in tourists' destination choices: Nature tours in Mexico. EJTHR, 8(1), 38-50.

[12] Kah, J. A., et al. (2015). Tourism geographies: An international journal of tourism space, 
place and environment. Tourism Geographies, 13(2), 209-233.

[13] Octavia, D. \& Tamerlane, A. (2017). The influence of website quality on online purchase intentions on agoda.com with e-trust as a mediator. Binus Business Review, 8(1), 9-14.

[14] Tandon, U., et al. (2017). Customer satisfaction as mediator between website service quality and repurchase intention: An emerging economy case. Service Science, 9(2), 106-120.

[15] Coursaris, C. K., et al. (2018). Antecedents and consequents of information usefulness in usergenerated online reviews: A multi-group moderation analysis of review valence. AIS Transactions on Human-Computer Interaction, 10(1), 1-25.

[16] Perpina, L., et al. (2020). Image and risk perceptions: An integrated approach. Current Issues in Tourism, 1-18.

[17] $\mathrm{Bi}$, J. \& Gu, C. (2019). Cultural distance and international tourists' intention to visit a destination. Asia Pacific Journal of Tourism Research 2019, 24(8), 839-849.

[18] Phau, I., et al. (2015). Looking beyond pasta and pizzas: Examining personal and historical nostalgia as travel motives. International Journal of Culture,Tourism and Hospitality Research, 10(3), 296-309.

[19] Houston, M. J. \& Rothschild, M. L. (1977). A paradigm for research on consumer involvement, 55.

[20] Giyanti, I. \& Suparti, E. (2018). Penilaian kualitas aplikasi halal MUI dengan webqual 4.0 dan pengaruhnya terhadap keputusan penggunaan.J@ti Undip: Jurnal Teknik Industri, 13(2), 91-98.

[21] Hasanov, K \& Khalid, H. (2015). The impact of website quality on online purchase intention of organic food in Malaysia: A webqual model approach. Procedia Computer Science: The Third Information Systems International Conference, $72,382-389$.

[22] Irawan, C. (2012). Evaluasi kualitas website pemerintah daerah dengan menggunakan webqual (studi kasus pada Kabupaten Ogan Ilir). Jurnal Sistem Informasi (JSI), 4(2), 488-502.

[23] Li, L., et al. (2017). An empirical study on the influence of economy hotel website quality on online booking intentions. International Journal of Hospitality Management, 63, 1-10.

[24] Suhendra, E. S. (2009). Faktor determinan manajemen kualitas pada situs perpustakaan. Jurnal Ekonomi Bisnis, 14(3), 200-207.

[25] Barnes, S. J. \& Vidgen, R. T. (2003). Measuring Web site quality improvements: a case study of the forum on strategic management knowledge exchange. Industrial Management \& Data Systems, 103(5), 297-309.

[26] Chiang, P. S. (2009). A study of measuring international young tourists' lifestyle, travel type, risk perceptions of travel, and travel satisfaction in Taiwan. Tamsui Osford Journal of Tourism, 3, 1-26.

[27] Promsivapallop, P. \& Kannaovakun, P. (2018). Travel risk dimensions, personal-related factors, and intention to visit a destination: A study of young educated German adults. Asia Pacific Journal Of Tourism Research, 23(7), 639-655. Quintal, V. A., et al. (2010). Risk, uncertainty and the theory of planned behaviour: A tourism example. Tourism Management, 31(6), 797-805.

[28] Khan, M. J., et al. (2019). Perceived risks, travel constraints and visit intention of young women travelers: The moderating role of travel motivation. Tourism Review, 74(3), 721-738.

[29] Simpson, P. M. \& Siguaw, J. A. (2008). Perceived travel risks: The traveller perspective and manageability. International journal of tourism research, 10, 315-327.

[30] Setyawan \& Ihwan. (2004). Pengaruh service quality perception terhadap purchase intentions: Studi empirik pada konsumen supermarket. Usahawan, 7, 29-37.

[31] Anoraga \& Pandji. (2000). Manajemen Bisnis. Jakarta: PT. Rineka Cipta.

[32] Newberry, et al. (2003). Managerial implications of predicting purchase behaviour from purchase intentions: A retail patronage case study. Journal of Service Marketing, 17(6), 609-620.

[33] Lee, W. I., et al. (2017). Effects among product attributes, involvement, word-ofmouth, and purchase intention in online shopping. Asia Pacific Management Review, 22(4), 1-7.

[34] Kim, D. J., et al. (2008). A trust-based consumer decision-making model in electronic commerce: The role of trust, perceived risk, and their antecedents. Decision Support Systems, 44(2), 544-564.

[35] Ferdinand, A. (2006). Metode Penelitian Manajemen: Pedoman Penelitian untuk Penulisan Skripsi, Tesis, dan Disertasi Ilmu Manajemen. Semarang: Badan Penerbit Universitas Diponegoro.

[36] Zhou, T., et al. (2009). The relative importance of website design quality and service quality in determining consumers' online repurchase behaviour. Information Systems Management, 26(4), 327-337.

[37] Nilashi, et al. (2016). Recommendation 
quality, transparency, and website quality for trust-building in recommendation agents. Electronic Commerce Research and Applications, based on online shopping influencing factors of website characteristics college students in kunming for the survey. Applied Mechanics and Materials, 389, 985-989.

[39] Lepp, A. \& Gibson, H. (2003). Tourist roles, perceived risk and international tourism. Annals of Tourism Research, 30(3), 606-624.

[40] Becken, S., et al. (2016). Urban air pollution in China: Destination image and risk perceptions. Journal of Sustainable Tourism, 25(1), 130-147.

[41] Edem, U. S. \& Lawal, O. O. (1997). Utilization of quantitative methods in decision making among Nigerian university librarians. Library
$19,70-84$.

[38] Yang, L., et al. (2013). Empirical analysis

Management, 18(1), 53-58.

[42] Montgomery, D. C. (2013). Design and Analysis of Experiments Eight Edition. Arizona: John Wiley \& Sons, Inc.

[46] Barnes, S. J. \& Vidgen, R. T. (2006). Data triangulation and web quality metrics: A case study in e-government. Information and Management, 43(6), 767-777.

[46] Lu, H. Y., et al. (2015). Influences on the perceived value of medical travel: The moderating roles of risk attitude, self- esteem and word-of-mouth. Current Issues in Tourism, 1-15. 